\title{
3D-Fluorescence Spectroscopic Analysis of HPLC Fractionated Estuarine Fulvic and Humic Acids
}

\author{
Marta M. D. Sierra, ${ }^{*, a}$ Marcelo Giovanela, $^{b, c}$ Edith Parlanti $^{d}$ and Eduardo J. Soriano-Sierra ${ }^{e}$ \\ ${ }^{a}$ Departamento de Química, Universidade Federal de Santa Catarina, 88040-900 Florianópolis-SC, Brazil \\ ${ }^{b}$ Centro Tecnológico e ${ }^{c}$ Departamento de Física e Química, Centro de Ciências Exatas e Tecnologia, \\ Universidade de Caxias do Sul, 95070-560 Caxias do Sul-RS, Brazil \\ ${ }^{d}$ Laboratoire de Physico-Toxicochimie des Systèmes Naturels (LPTC) - UMR 5472 CNRS, Université Bordeaux I, \\ 351 Cours de la Libération, 33405 Talence Cedex - France
}

${ }^{e}$ Núcleo de Estudos do Mar, Universidade Federal de Santa Catarina, 88040-900 Florianópolis-SC, Brazil

\begin{abstract}
Seis amostras de ácidos fúlvicos $(\mathrm{AF})$ e húmicos $(\mathrm{AH})$ estuarinos foram fracionadas por meio de cromatografia líquida de alta performance em fase reversa, num gradiente de polaridade água $\rightarrow$ acetonitrila, com detecção por fluorescência. Diferenças entre os cromatogramas mostraram que os AH contêm mais componentes hidrofóbicos que os AF. Os espectros de fluorescência tridimensional das frações foram bastante similares entre si e também ao da amostra original, indicando que, apesar das polaridades distintas, a complexidade e as principais características do material original se mantêm. Um mesmo grupo de fluoróforos parece ser responsável pelas características de fluorescência, dos dois tipos de substâncias húmicas. Um deslocamento batocrômico dos espectros de emissão das soluções originais, com relação àqueles das frações, foi atribuído a uma maior proximidade destes fluoróforos, possivelmente devido à formação de agregados. Em geral, os resultados confirmam o conceito de que as "macromoléculas" húmicas consistem de associações de estruturas menores com características químicas semelhantes.
\end{abstract}

Six estuarine fulvic (FA) and humic acids (HA) were fractionated with reversed-phase high performance liquid chromatography in a water/acetonitrile gradient, with fluorescence detection. Differences between FA and HA chromatograms pointed to a higher incidence of hydrophobic components in the latter. Excitation-emission matrix fluorescence diagrams of most fractions were similar to those of the bulk samples indicating that, in spite of their distinct polarities, the complexity and main spectral characteristics of the materials persisted. A primary group of fluorophores, which are present in most of the fractions, seems to be at the origin of the fluorescence properties of both kinds of HS. A bathochromic shift of the bulk solutions spectra in relation to the fraction emissions was attributed to a greater proximity of these fluorophores, possibly due to the formation of aggregates. Generally, the results reinforced concepts that humic macromolecules consist of assemblages of structurally similar building blocks.

Keywords: RP-HPLC, fulvic acids, humic acids, EEM fluorescence

\section{Introduction}

Humic substances (HS) are complex macromolecular products resulting from the chemical and biological degradation of plant and animal residues. They are widely distributed in soils, natural waters, and sediments, and represent a significant proportion of the organic carbon in the global carbon cycle. ${ }^{1-4}$ According

* e-mail: sierra@qmc.ufsc.br to current estimates, HS constitute the major fraction of soil organic matter (up to $80 \%$ ) and the largest fraction of natural organic matter (NOM) in aquatic systems (up to $60 \%$ of dissolved organic carbon). ${ }^{5,6}$ These organic materials can have a substantial impact on a variety of biogeochemical processes, for example, immobilizing anthropogenic organic chemicals and heavy metals..$^{7-11}$

The elucidation of the HS molecular sizes, shapes, weights and structural arrangements is essential for an 
adequate understanding of their varied role in such environmental processes. This has led to increasing efforts toward the characterization of these compounds and as a result, a variety of spectroscopic and separation techniques have been used. Among the various separation methods proposed for HS characterization, molecular size fractionation by high performance size exclusion chromatography (HPSEC) and reversed-phase high performance liquid chromatography (RP-HPLC), have been the most employed. HPSEC reveals molecular size distributions as well as number- and weight-averaged HS molecular weights. ${ }^{12-19}$ Using HPLC, HS can be separated into fractions of compounds with a multi-component nature with polarity as a common characteristic. ${ }^{15-19}$ In general, UV absorbance, and/or fluorescence spectroscopy have been the preferred detection methods. Recently, HPSEC with UV absorbance and fluorescence spectroscopy plus on-line dissolved organic carbon (DOC) detection has been used to characterize NOM as a function of molecular size. ${ }^{20,21}$ Although, generally, these studies demonstrate how difficult it is to isolate individual compounds, they have significantly contributed to an understanding of the complex nature of HS.

In this paper, we report a comparative study of the fluorescence properties of estuarine fulvic (FA) and humic acids (HA) before and after RP-HPLC fractionation, using three-dimensional excitation-emission matrix (EEM) fluorescence spectroscopy. EEM produces fluorescence spectra at many different excitation wavelengths providing an overall view of all features existing within a selected spectral range. This technique has, since 1990, satisfactorily been used to investigate water masses in natural environments but reports on its utilization in NOM and HS fractionation studies have only recently appeared in the literature..$^{21-30}$ Briefly, Parlanti et al. ${ }^{29}$ have shown that the detailed off-line analysis of EEM fluorescence diagrams of NOM fractions allows the differentiation between marine and fresh water samples and Wu et al., ${ }^{30}$ with on-line EEM fluorescence detection, found strong relationships between molecular size, fluorescence pattern and polarity for both NOM and HS, with the humic, fulvic and protein-like fluorescence fractions presenting distinct hydrophilic/hydrophobic natures.

In this study, HS were fractionated, with a polymeric $\mathrm{C}_{18}$ as the stationary phase, using a polarity gradient from pure water to pure acetonitrile, and a fluorescence detector. ${ }^{29}$ In order to present an in-depth analysis of the data and also to compare our findings to related studies, a few single-scan spectra are also included.

\section{Experimental}

\section{Origin of humic substances}

FA and HA samples were obtained, according to the International Humic Substances Society (IHSS) recommended procedure, from mangrove sediments on Santa Catarina Island (Southeast Brazil) and experimental details have been published elsewhere. ${ }^{31}$ The samples studied here form part of a set of estuarine, marine and terrestrial HS that have been exhaustively investigated in order to compare their structural, spectral and functional properties. ${ }^{31-33}$

\section{Reversed-Phase High Performance Liquid Chromato- graphy (RP-HPLC)}

RP-HPLC separations were performed using a Hewlett Packard HPLC system (model HP 1100 series) equipped with a $100 \mu \mathrm{L}$ loop injector, a quaternary pump and a fluorescence detector. Commercial pre-packed analytical HPLC column $(250 \times 4.6 \mathrm{~mm}$ I.D. $)$ was purchased from SHODEX ASAHIPAK (Germany). An octadecyl polymer with a $5 \mu \mathrm{m}$ particle size and $100 \AA$ pore size was chosen as the stationary phase. The guard column $(20 \times 4 \mathrm{~mm}$ I.D. $)$ contained the same packing material as the analytical column.

The chromatograms were obtained using an elution gradient from $100 \%$ Milli-Q water to $100 \%$ acetonitrile, held for $30 \mathrm{~min}$, followed by a 10-min linear gradient to $100 \%$ acetonitrile (Figure 1). The flow rate was $0.5 \mathrm{~mL}$ $\min ^{-1}$ and the injection volume was $50 \mu \mathrm{L}$. Each HPLC fraction was collected manually and represents the result of ten successive runs. After collection the solvent was evaporated under nitrogen flow. The dried sub-samples were kept at $4^{\circ} \mathrm{C}$ in the dark until fluorescence analysis. To record the fluorescence spectra each fraction was dissolved in $5 \mathrm{~mL}$ of Milli-Q water.

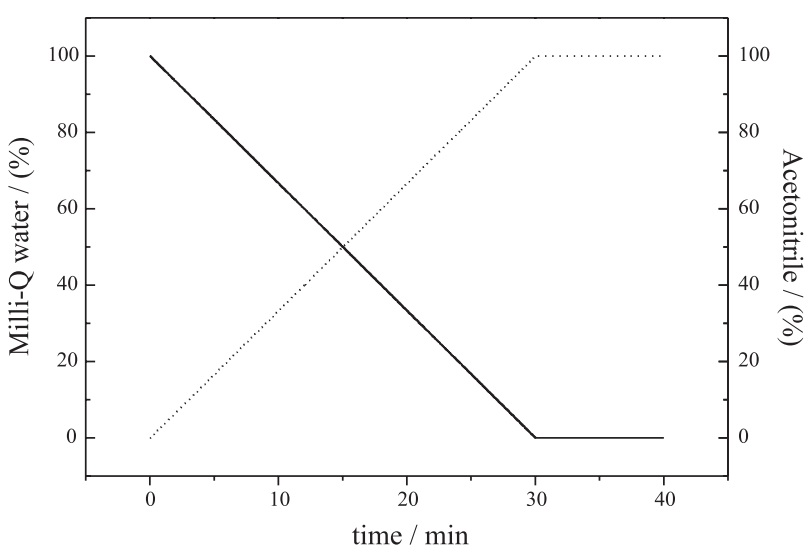

Figure 1. Gradient program for HS fractionation. (-) Milli-Q water, (- - ) acetonitrile. 


\section{Excitation-Emission Matrix (EEM) spectroscopy}

The fluorescence spectra of the FA and HA solutions (4 $\mathrm{mg} \mathrm{L}^{-1}$ of HS, $\mathrm{pH} \sim 7$ ) and of their corresponding HPLC fractions - whose concentrations, in a gross approximation, varied from near to 0 to approximately $3 \mathrm{mg} \mathrm{L}^{-1}$, depending on the polarity of the fraction, were recorded with a Fluorog FL3-22 SPEX-Jobin Yvon fluorometer. This apparatus is equipped with double monochromators for both excitation and emission sides, giving them a low straylight level. All samples were contained in a $1 \mathrm{~cm}$ path length fused silica cell (Hellma), thermostated at $20{ }^{\circ} \mathrm{C}$.

The fluorescence EEM spectroscopy involved scanning and recording 17 individual emission spectra $(260-700 \mathrm{~nm})$ at sequential $10 \mathrm{~nm}$ increments of excitation wavelength between 250 and $410 \mathrm{~nm}$. The bandwidths for excitation and emission were $4 \mathrm{~nm}$, with emission wavelength increments of $1 \mathrm{~nm}$ and an integration time of $0.5 \mathrm{~s}$. The spectra were obtained by subtracting Milli-Q water blank spectra, recorded under the same conditions, to eliminate water Raman scatter peaks. The 17 scans were used to generate three-dimensional contour plots of fluorescence intensity as a function of excitation and emission wavelengths. At the data collection intervals used in this study, EEM results in discrete measurements of fluorescence intensity at 7497 excitation/emission (exc/emi) wavelength pairs. To make the graphs readable, the topographic and contour EEM plots are presented in this paper with excitation and emission of 10 and $5 \mathrm{~nm}$, respectively.

\section{Results and Discussion}

\section{Fluorescence characteristics of FA and HA}

The EEM fluorescence and the respective threedimensional projections of aqueous solutions of the estuarine HS samples can be seen in Figure 2. Diagrams like these have already been shown and discussed in detail. ${ }^{33}$ Briefly, two main characteristic ranges of fluorescence intensity can be distinguished in these diagrams. For FA, the first and more intense region is centered at exc/emi $=260 \mathrm{~nm} / 460 \mathrm{~nm}$ and the second, less intense, is close, being at exc/emi $=310 \mathrm{~nm} / 440 \mathrm{~nm}$. For HA, these two regions are located at around exc/emi $=260 \mathrm{~nm} / 525 \mathrm{~nm}$ and exc/emi $=360 \mathrm{~nm} / 520 \mathrm{~nm}$, respectively, the latter appearing more like a shoulder. Considering their overall shape these EEM are similar to those of natural, mainly fresh and pore, waters. ${ }^{24,26,29,34}$ The fluorophores responsible for these two main signals have already been recognized as belonging to typical humiclike components, having received individual designations such as, $\mathrm{A}$ and $\mathrm{C}$ or, $\alpha^{\prime}$ and $\alpha$, respectively. ${ }^{24,26,29,34}$ Our observations extend only to $\lambda_{\text {exc }}=250 \mathrm{~nm}$ and because of this, for the FA sample whose excitation ranges extend towards the blue-end, the $\alpha^{\prime}$ peak is only partially registered. Such an effect does not hinder an assessment of the maximum wavelength value.

Besides these two main fluorescence regions, these samples present a third signal. For FA, it is located within the range exc/emi $=270-280 \mathrm{~nm} / 305-320 \mathrm{~nm}$ and, for $\mathrm{HA}$, in the range exc/emi $=270-280 \mathrm{~nm} / 330-345 \mathrm{~nm}$. This signal is present in the HS diagrams with varied intensities. ${ }^{33}$ For natural waters, fluorescence signals within this range have usually been attributed to proteinderived compounds being designated as B or $\gamma$ (tyrosine and/or protein-like peak with $\lambda_{\text {emi }} \sim 310 \mathrm{~nm}$ ) and as T or $\delta$ (tryptophan and/or protein-like peak, with $\lambda_{\text {emi }} \sim 340 \mathrm{~nm}$ ) fluorophores. ${ }^{24,26}$ The peaks in this range of the fluorescence spectra and EEM diagrams have been used as markers to estimate biological activity and the different stages of the biological production in coastal zones. ${ }^{26,35}$ According to Parlanti et al. ${ }^{26}$ the more prominent the $\gamma$ peak the earlier the stage of degradation of the freshly produced biological material, in natural waters.

Some estuarine HA from this same pool of samples showed a fourth and barely perceptible shoulder at around exc/emi $=320 \mathrm{~nm} / 425 \mathrm{~nm}$ which has been associated with the presence of marine humic-like compounds $(\beta$ components)..$^{24,26,33,36}$ In EEM diagrams for natural waters the $\beta$ signal has been observed in association with the protein-like, mainly the $\gamma$, peaks suggesting that both components have the same biological origin. ${ }^{26}$ In fact, the $\beta$ fluorophore should be present to varied extents in all diagrams of our estuarine HS but its signal might be overlapped by the stronger fluorescence (mainly in FA diagrams) of the humic-like $(\alpha)$ peak. In HA, the emission ranges are red-shifted to above $520 \mathrm{~nm}$ making, consequently, more room for the $\beta$ peak appearance. Estuaries are highly productive environments, with considerably high sedimentation rates, and the signals for the presence of recent OM in these extracted HS confirms its relatively low humification degree. From the elemental, functional and spectral properties of these samples it was also inferred that they preserve significant moieties of the source materials. ${ }^{31-33,37}$

\section{RP-HPLC chromatograms}

Six estuarine FA and HA were fractionated in a polarity gradient from hydrophilic to hydrophobic components and general aspects of the chromatograms were basically the same, regardless of the sediment sample location. Figure 

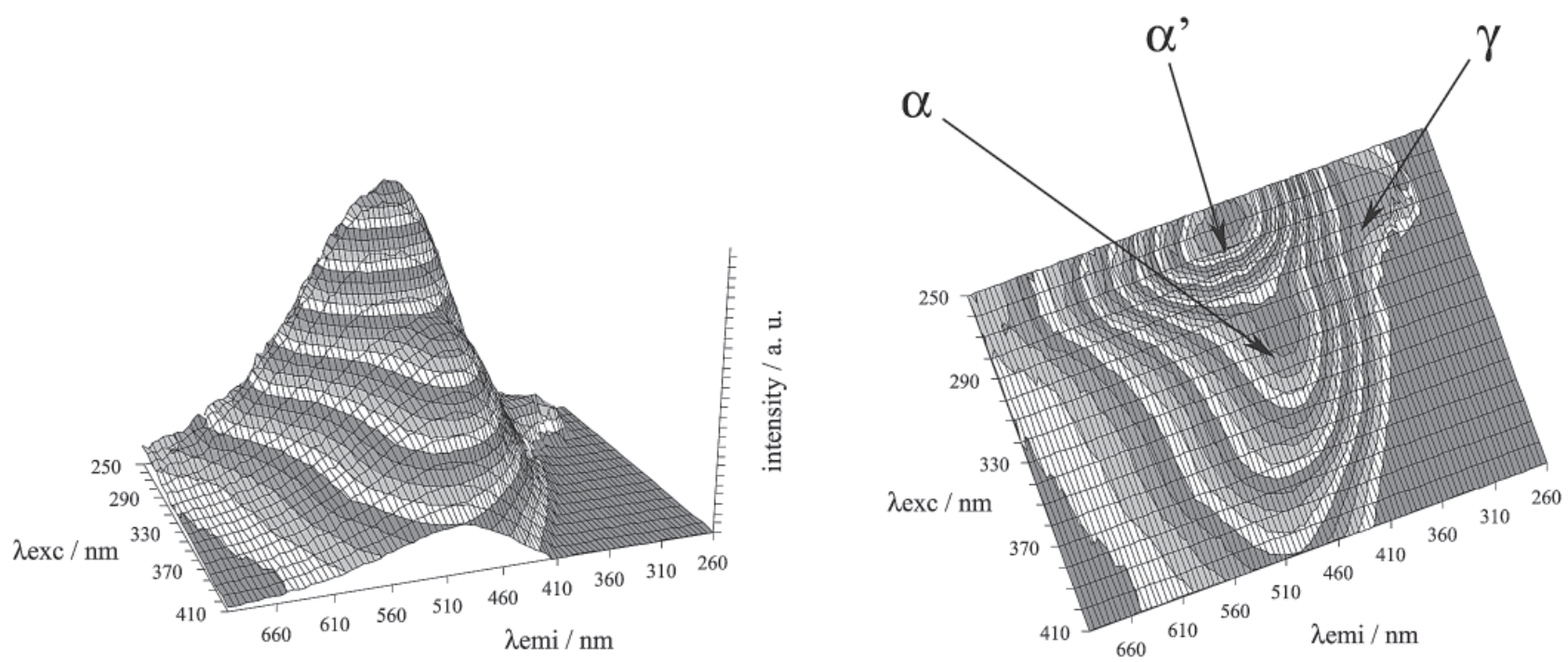

RME $1 A-F A$
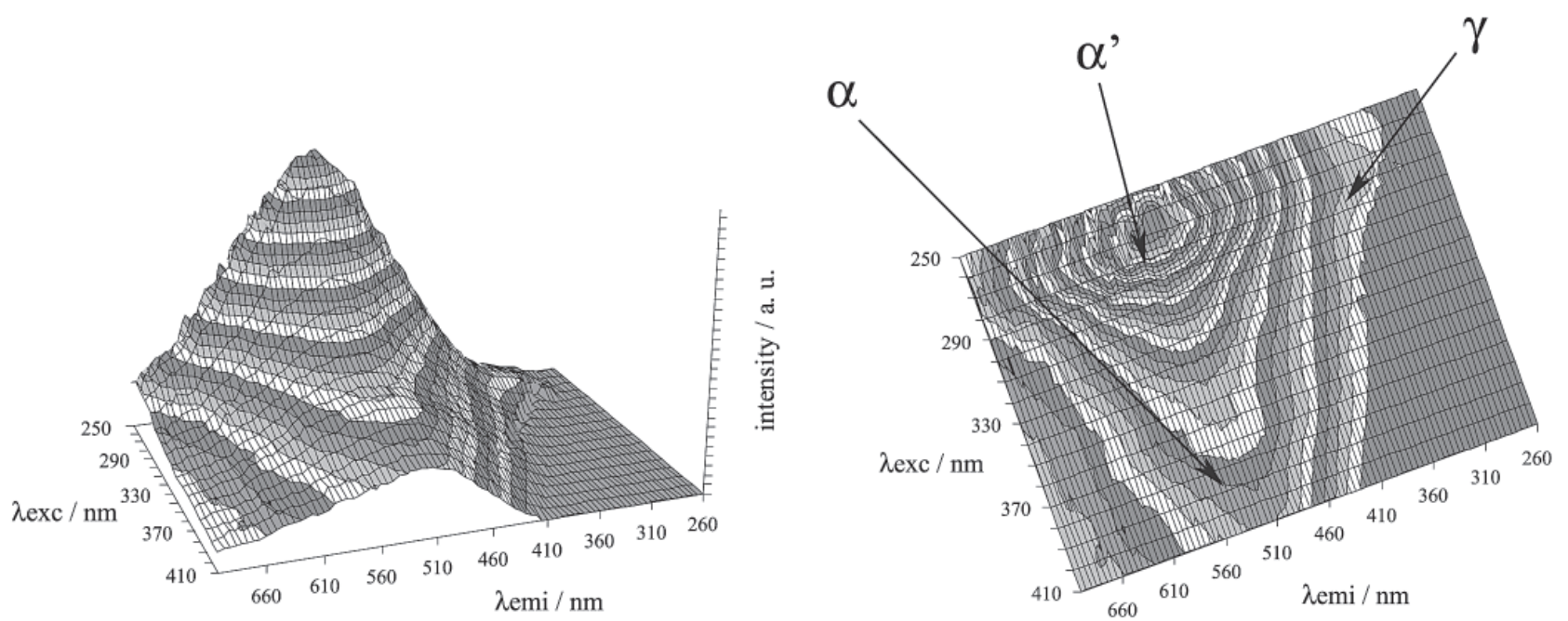

RME $1 A-H A$

Figure 2. Topographic and contour EEM plots for the FA and HA bulk sample aqueous solutions (4 $\left.\mathrm{mg} \mathrm{L}^{-1}\right)$.

3 shows two typical chromatograms of these estuarine HS samples. The $\lambda_{\text {exc }}=320 \mathrm{~nm}$ generates the $\alpha$ peak for both FA and HA and has already been used to detect fluorescence in natural water chromatographic fractions. ${ }^{29}$ Using the same wavelength would allow comparisons between our and their data. Two emission wavelengths were employed: 390 and $440 \mathrm{~nm}$. With the former the resolution and intensity of HA chromatograms in the 12-15 min retention range increased slightly when compared to the chromatograms obtained with the latter wavelength, but the general features were virtually the same. The intention of using this emission wavelength was to detect whether the $\beta$ components were present.

Two main regions can be distinguished in all chromatograms. For FA, within the 2.5 to approximately $7 \mathrm{~min}$ retention time range (more hydrophilic components), three to four peaks are well evidenced. Also for FA, between an $8 \mathrm{~min}$ and approximately 11 min retention time, no fluorescence signal was detected for any sample. Around a retention time of 12-14 min (more hydrophobic components), an intense and thin peak superposed to one or two small signals, depending on the sample, can be seen. After 15 min retention time no fluorescence signal was observed for any sample. 

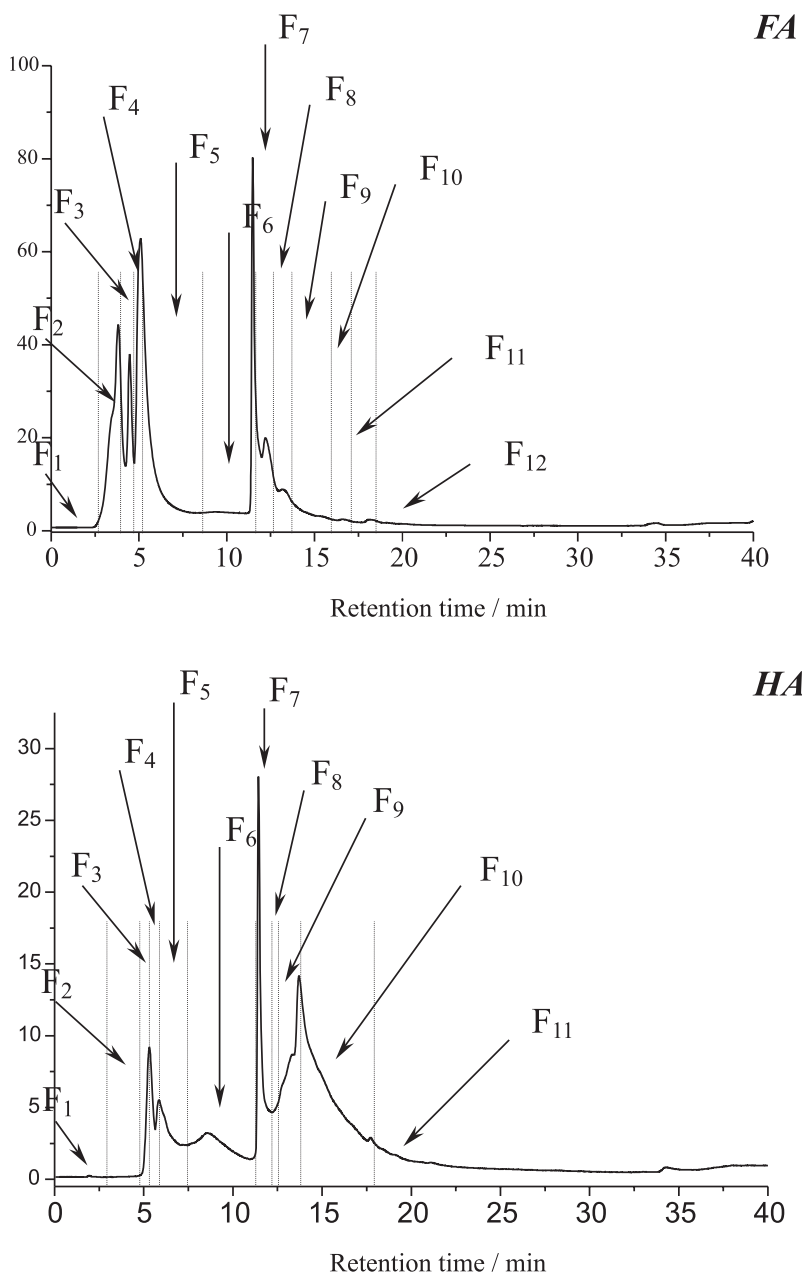

Figure 3. HPLC peaks for the estuarine HS obtained with a fluorescence detector $\left(\lambda_{\text {exc }}=320 \mathrm{~nm} / \lambda_{\text {emi }}=440 \mathrm{~nm}\right)$.

At this stage the percent of acetonitrile in the elution solution was approximately 50\% (Figure 1) indicating that even the less polar components in FA are relatively hydrophilic. The HA chromatograms were slightly different from those of FA. For HA the first chromatographic signal is seen only after a retention time of 5 min indicating that even its more hydrophilic components are less hydrophilic than those in FA. Also, in the lower retention time range (5-7 $\mathrm{min})$ the fluorescence signals are weaker than those in the FA chromatograms and, in general, only two superposed peaks can be distinguished. Contrary to FA, for most $\mathrm{HA}$, in the range of retention time between 8 and 10 min, a weak fluorescence signal is detected. At around $12 \mathrm{~min}$, as in the FA chromatograms, a thin and intense peak appears. Unlike FA, however, for all HA, a broad peak appears above 13 minutes (more hydrophobic components). This peak is slightly more defined when the $390 \mathrm{~nm}$ emission wavelength is used instead of the $440 \mathrm{~nm}$. Fluorescent components were detected until a
20 min retention time (approximately $60 \%$ acetonitrile, Figure 1), these being, consequently, slightly more hydrophobic than those of FA. In some aspects the chromatograms shown here are similar to those presented by Woelki et al. ${ }^{15}$ using a similar water/ acetonitrile gradient program. Differences between FA and HA chromatograms are, in fact, in perfect agreement with what is known about the solubility characteristics of these humic fractions, i.e., they indicate a higher incidence of more polar components in FA, and a higher incidence of more hydrophobic portions in HA mixtures.

\section{D-Fluorescence of the fractions}

According to the corresponding chromatographic signals eleven sub-fractions were collected for a HA and twelve for a FA estuarine sample. The EEM diagrams and the corresponding three-dimensional projections of some of these chromatographic fractions are shown in Figures 4 and 5. The succession of thin peaks occurring transversally from exc/emi $=250 \mathrm{~nm} /$ $500 \mathrm{~nm}$ to exc/emi $=350 \mathrm{~nm} / 700 \mathrm{~nm}$ in most diagrams corresponds to the second order Rayleigh scattering peak. Even after the Milli-Q water blank subtraction, part of the Rayleigh signal remains because it is more intense in HS solutions than in pure water. ${ }^{36}$ For the bulk samples (Figure 2) this does not occur, because, for these, humic fluorophores are present in a higher concentration, and their fluorescence intensity exceeds that of the light scattering that they provoke in solutions. Observe that for some HPLC fractions the scattering noise is also not significant. Also, the higher concentrations of chromophores in the bulk solutions mean that more light is absorbed. Photons that get absorbed do not get scattered.

The fluorescence diagrams generated by the fractions present virtually the same features as those of the bulk samples being, however, markedly shifted toward the blueend by comparison. In order to better visualize this effect single emission spectra representing the $\alpha^{\prime}\left(\lambda_{\text {exc }}=270 \mathrm{~nm}\right)$ and the $\alpha\left(\lambda_{\text {exc }}=320 \mathrm{~nm}\right)$ peaks are shown in Figures 6 and 7. For the FA, differences between the fluorescence maxima of the bulk samples and those of the fractions are minor but, for the HA, the maxima for fraction emissions are strongly blue-shifted in relation to the bulk samples. For the two excitation wavelengths, the fluorescence maxima of FA and HA fractions are located within the same wavelength range $(435 \mathrm{~nm}-450 \mathrm{~nm}$ ) indicating that a primary group of fluorophores is responsible for the fluorescence properties of the two kinds of HS. From these 

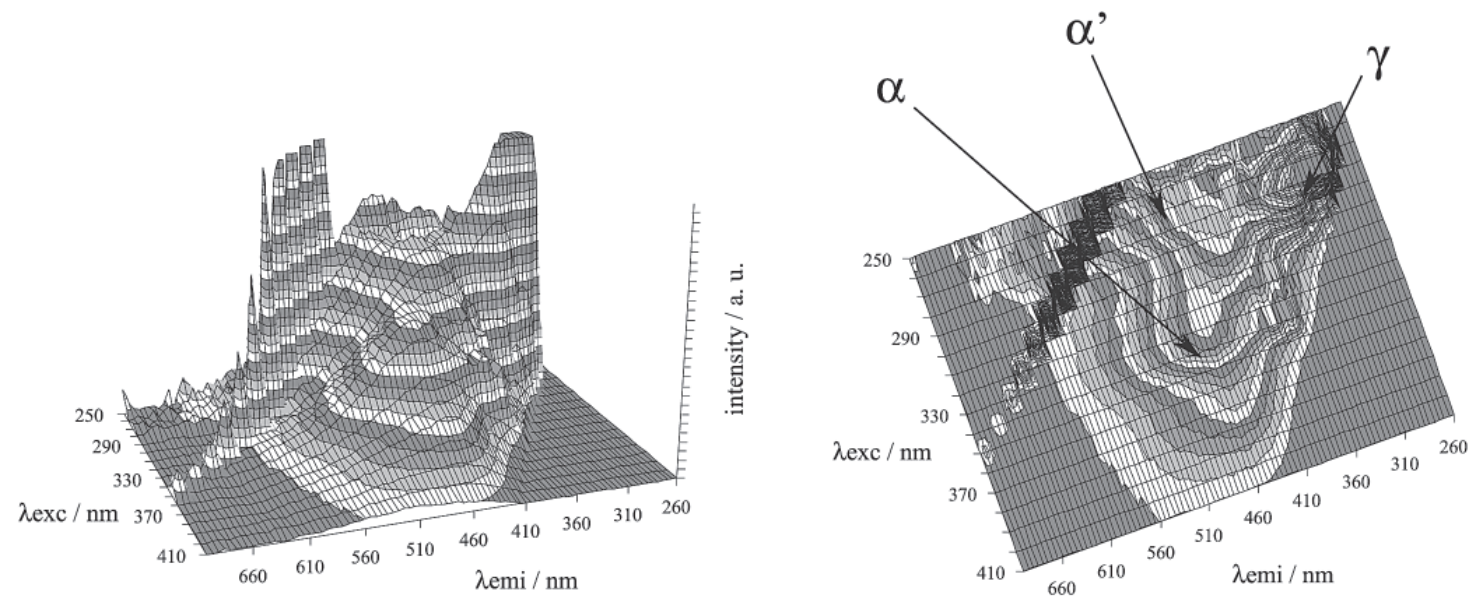

\section{$\operatorname{HPLC} F_{1}$}
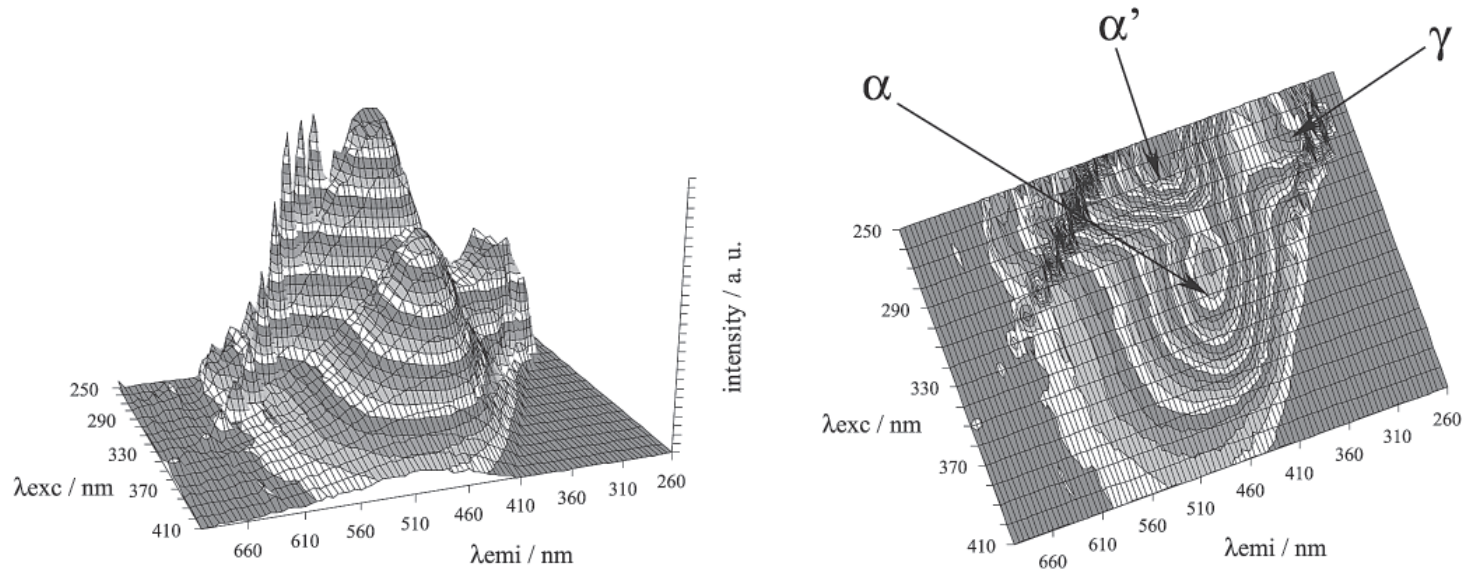

\section{$\mathrm{HPLC} \mathrm{F}_{3}$}
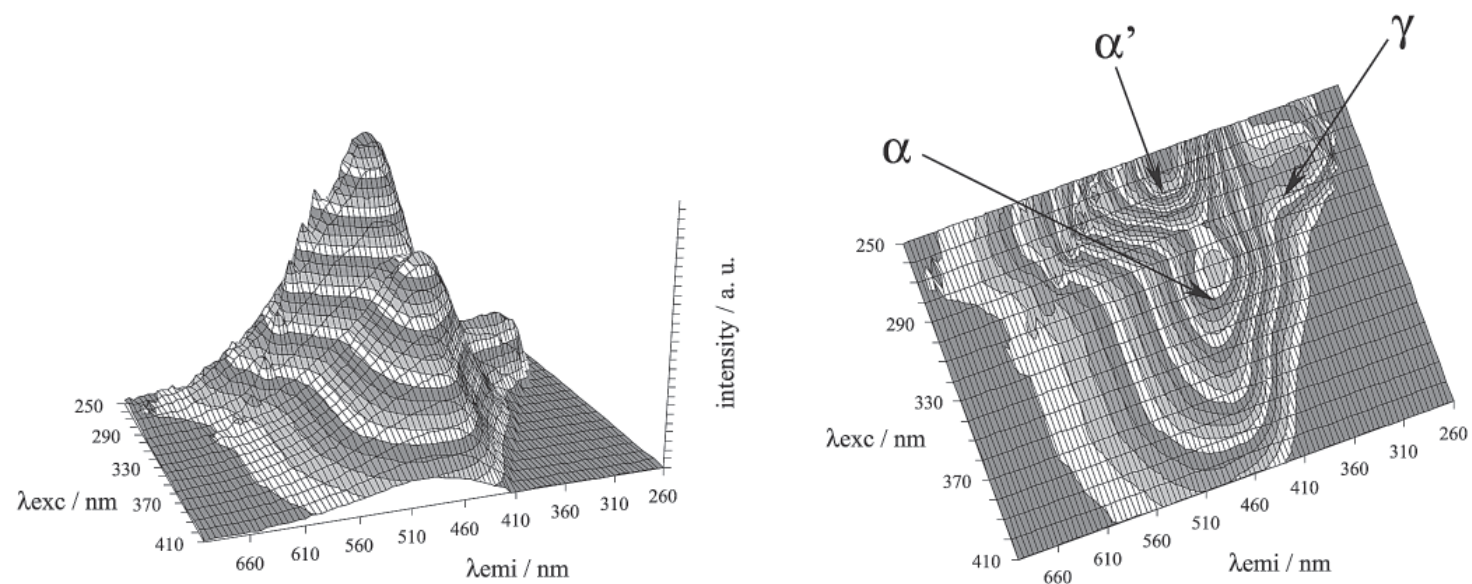

\section{$\mathrm{HPLC} \mathrm{F}_{5}$}

Figure 4. Topographic and contour EEM plots for a few FA fractions. 

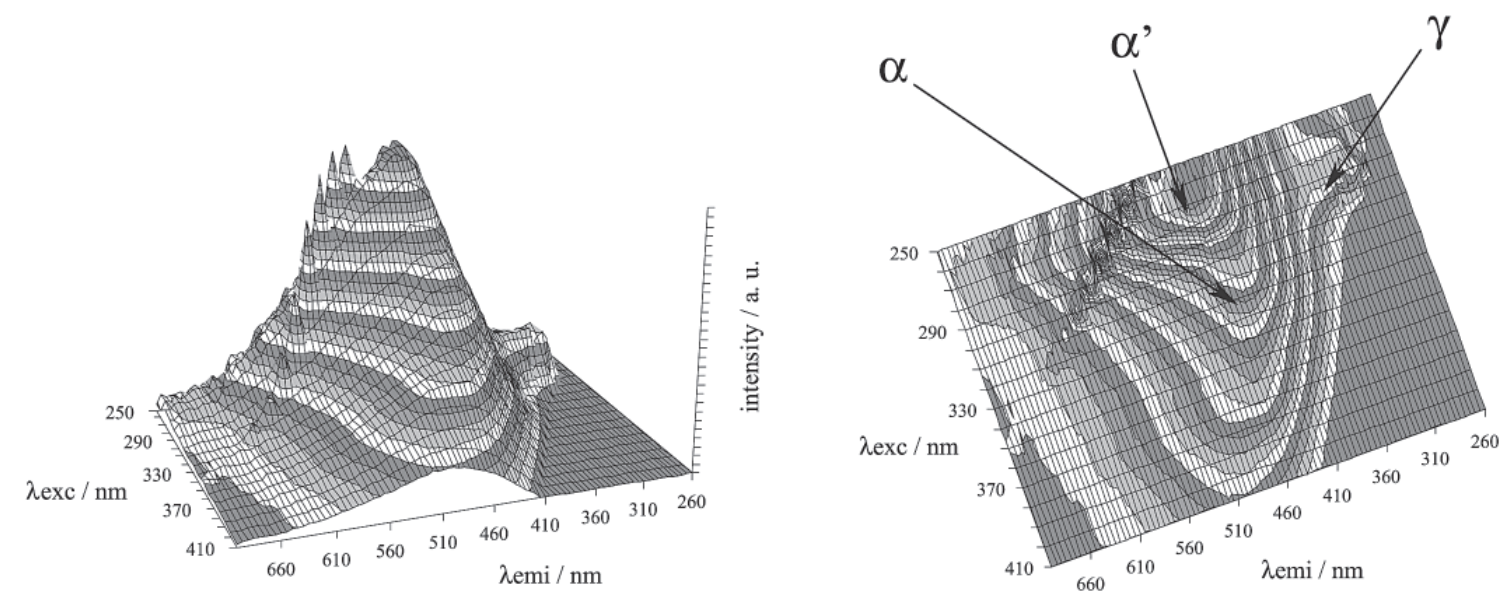

\section{$\mathrm{HPLC} \mathrm{F}_{7}$}
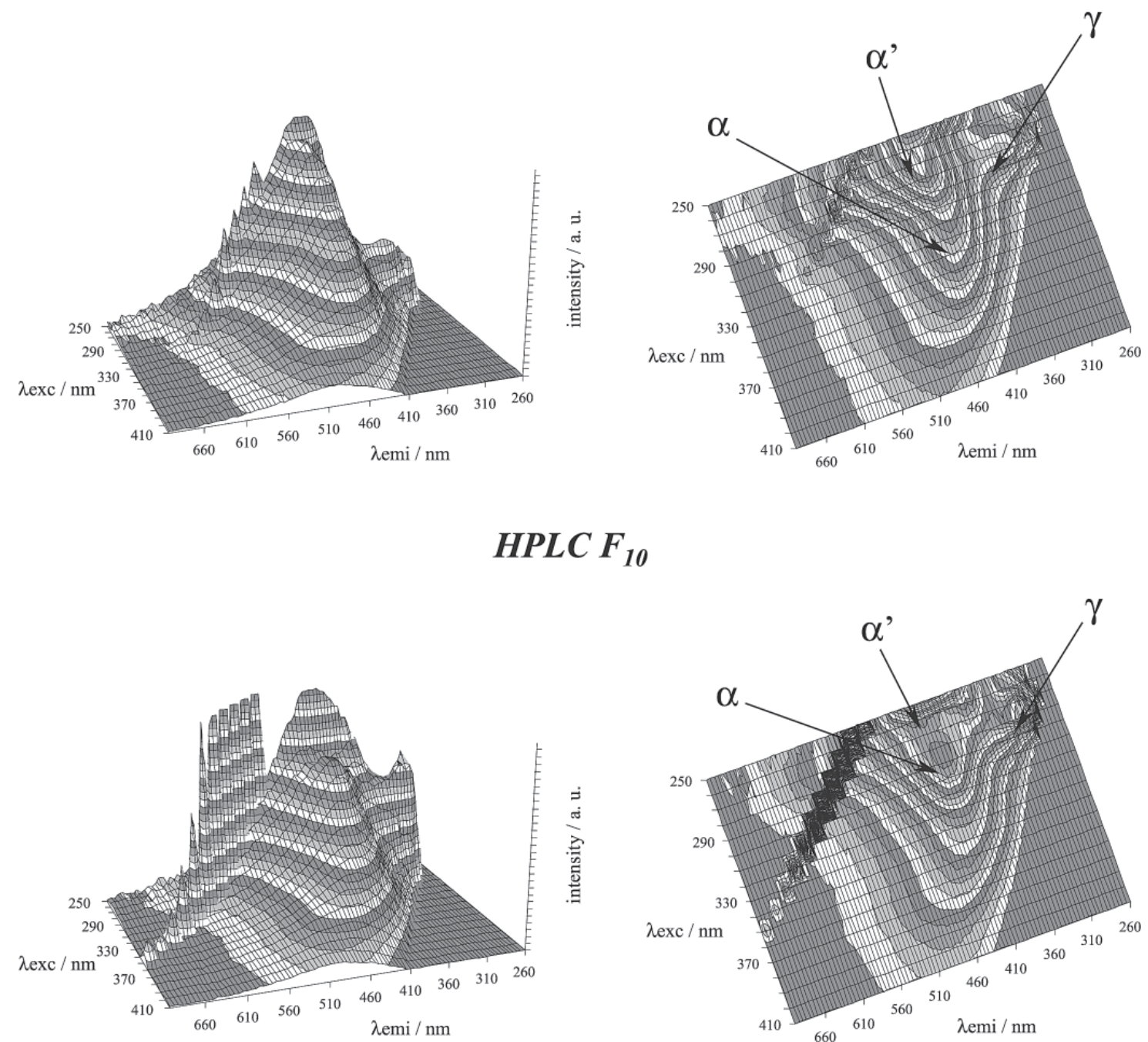

$\mathrm{HPLC} \mathrm{F}_{10}$

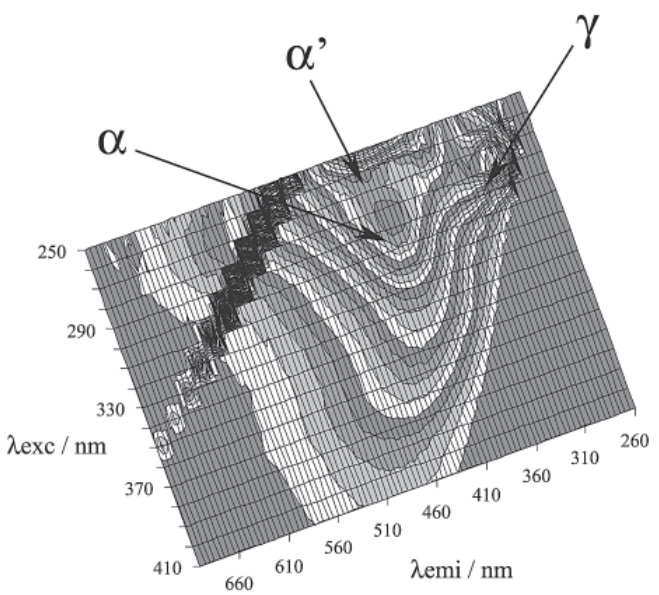

\section{$\mathrm{HPLC} \mathrm{F}_{12}$}

Figure 4. (cont.) 

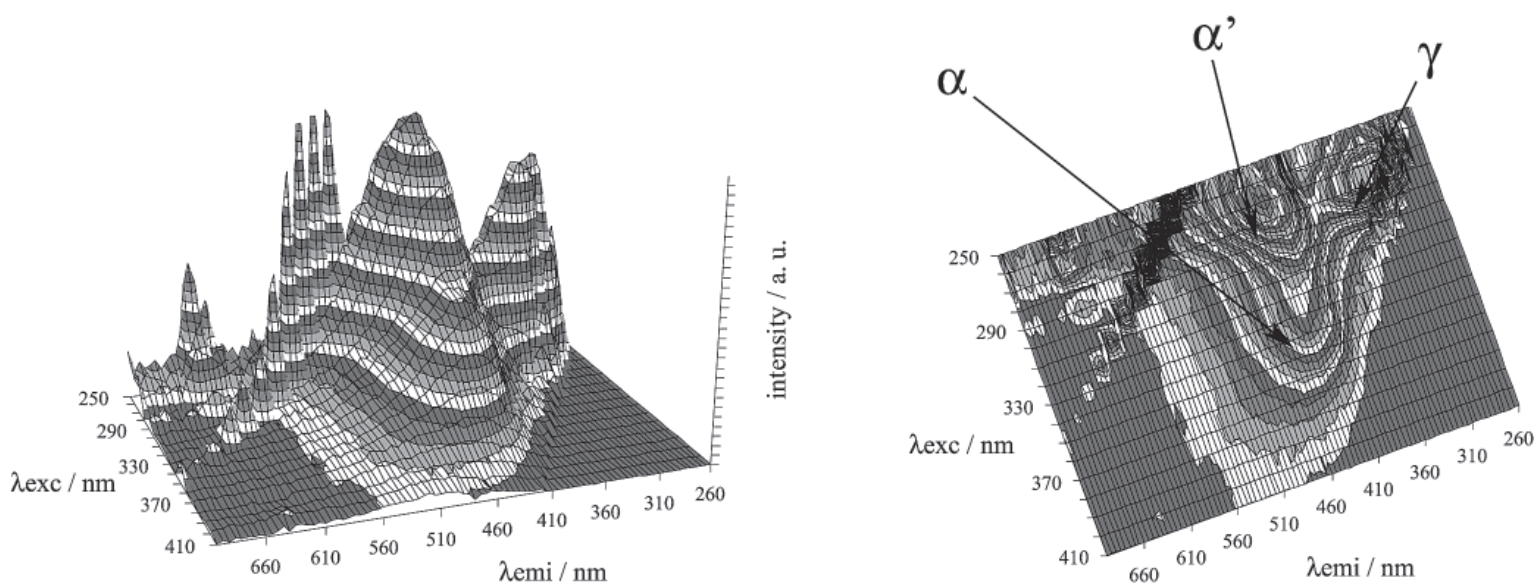

\section{$\mathrm{HPLC} \mathrm{F}_{1}$}
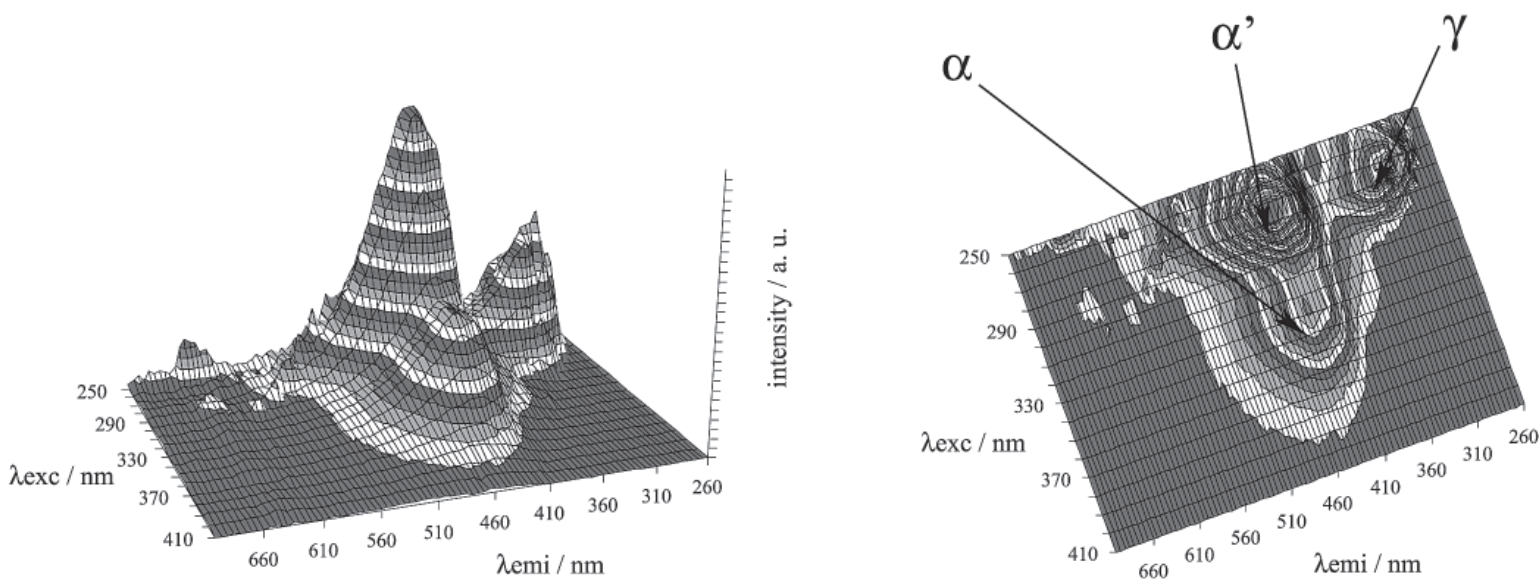

\section{$\mathrm{HPLC} \mathrm{F}_{2}$}
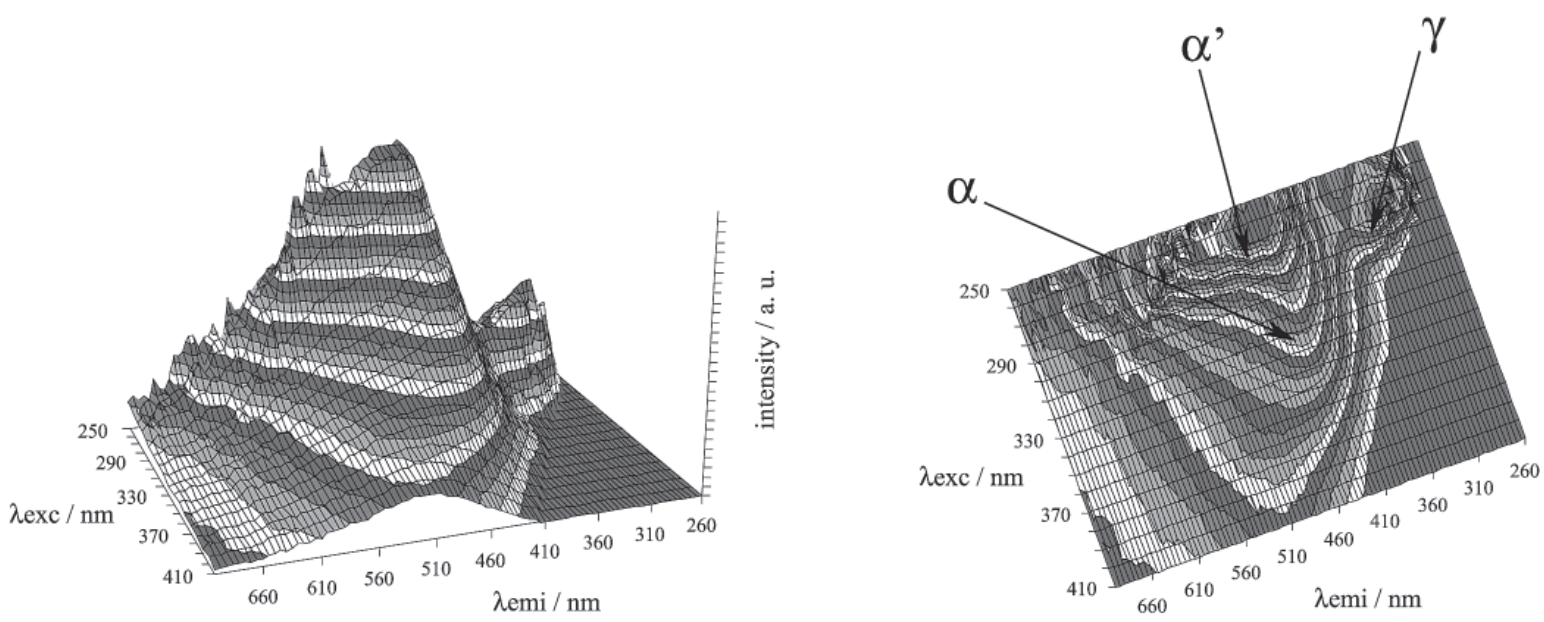

\section{$\mathrm{HPLC} \mathrm{F}_{6}$}

Figure 5. Topographic and contour EEM plots for a few HA fractions. 

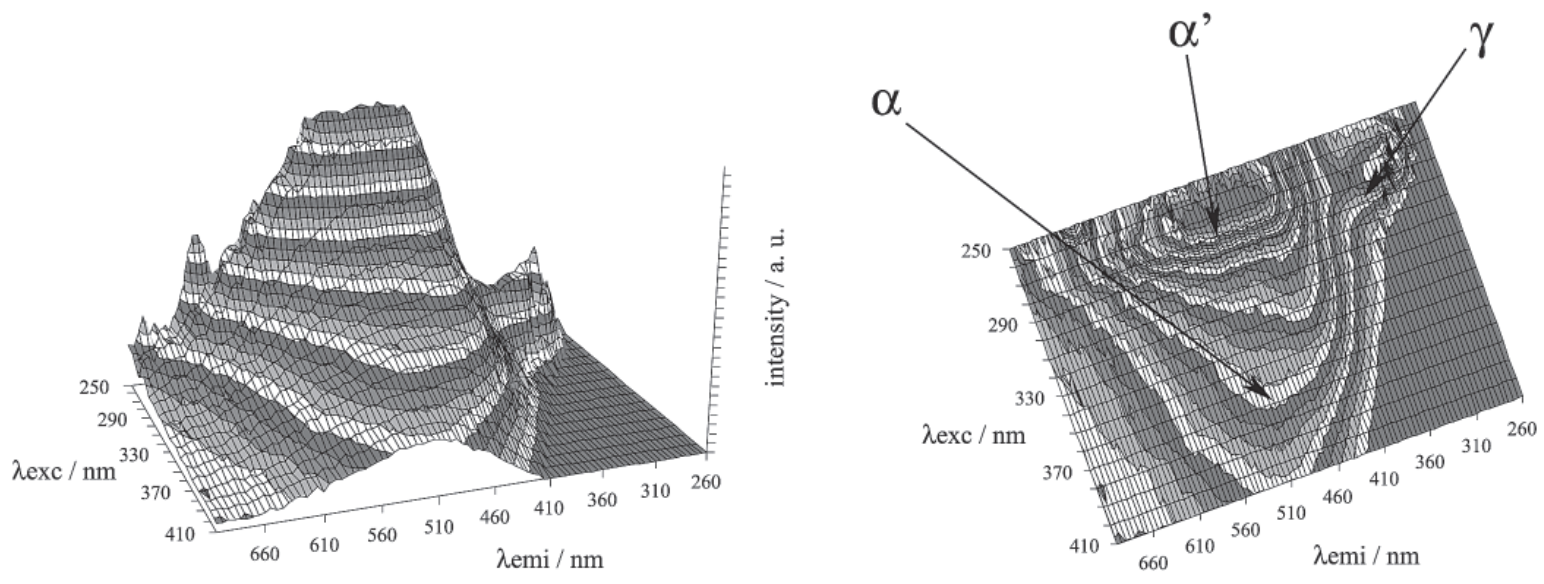

\section{$\mathrm{HPLC} \mathrm{F}_{7}$}
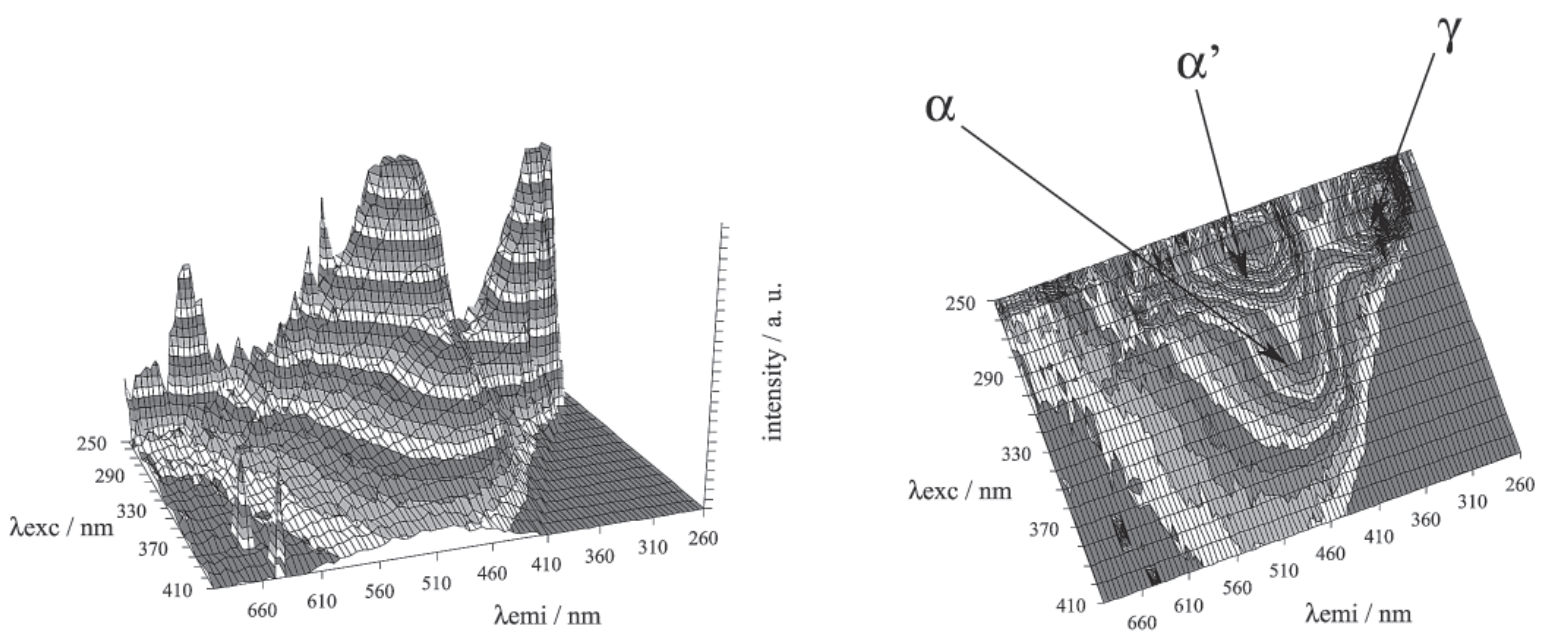

\section{$\mathrm{HPLC} \mathrm{F}$}
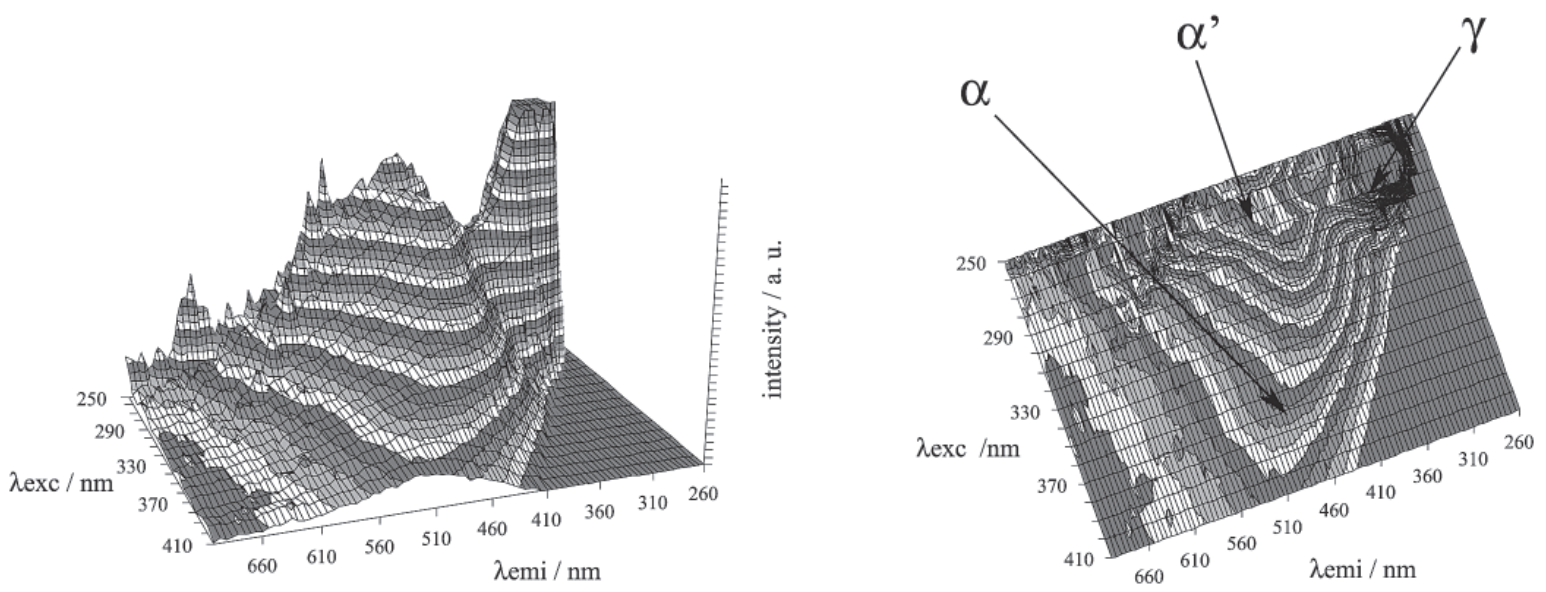

\section{$H_{P L C ~} F_{11}$}

Figure 5. (cont.) 
data it can equally be inferred that such fluorophores are present in basically all fractions regardless of the fraction polarity characteristics. Woelki et al..$^{15}$ and Lombardi and Jardim $^{6}$ reached similar conclusions studying fractionated HS. The bathochromic shift in the bulk samples emission might therefore be a consequence of the greater proximity of such fluorophores - in general, aromatic moieties deactivating part of the excited states and shifting the maxima to higher wavelengths. ${ }^{38}$ Results like these reinforce concepts on HS structures according to which, they consist of assemblages of building blocks, with similar structural features. ${ }^{39-42}$ Another possible effect to be considered, which does not exclude the above cited phenomenon, is that recently emphasized by Del Vecchio and Blough. ${ }^{43}$ On analyzing the results of laser photobleaching experiments, they proposed that the long wavelength absorption tail of HS arises from a continuum of coupled states resulting from intramolecular charge-transfer interactions between hydroxy-aromatic donors and quinoid acceptors, the emitting states populated by longer wavelength excitation being a lower energy subset of those populated by shorter wavelength excitation. ${ }^{43}$ Following these concepts we propose that supramolecular phenomena like hydrogen bonding, van der Waals forces and/or hydrophobic interactions maintain the proximity between "monomers" in solution. Strong exchanges between the HS hydrophobic domains and the stationary phase during fractionation, however, disrupt part of these associations leading to the separation of the blocks, and consequently of the fluorophore assemblages, resulting in a blue shift of the fluorescence signal. If such a shift were mostly a solvent effect, it should be gradual, with the more hydrophilic fractions showing maxima closest to those of the bulk sample aqueous solutions and so on. The greater displacement observed for HA compared to FA, on the other hand, is probably a consequence of the greater number of aromatic moieties present in the formers. Moreover, several studies have shown that HA can aggregate inter and/or intramolecularly in aqueous solutions generating micelle-like agglomerates capable of sequestering hydrophobic pollutants. ${ }^{44-47}$ The formation of such agglomerates, which is influenced by the concentration, $\mathrm{pH}$, ionic strength and the presence of non-polar compounds, has been evidenced in HA, but not in FA, solutions of the same pool of HS studied here. ${ }^{45,47}$ In HA bulk solutions the greater proximity of the aromatic moieties would then occur in the interior of such hydrophobic microdomains, explaining the strongest spectral displacement. A few HA fractions (particularly fractions 6 and 7) exhibit, besides the main signal at 450 $\mathrm{nm}$, a shoulder in the same wavelength range $(\sim 530 \mathrm{~nm})$ as that of the bulk sample emission, indicating that in these
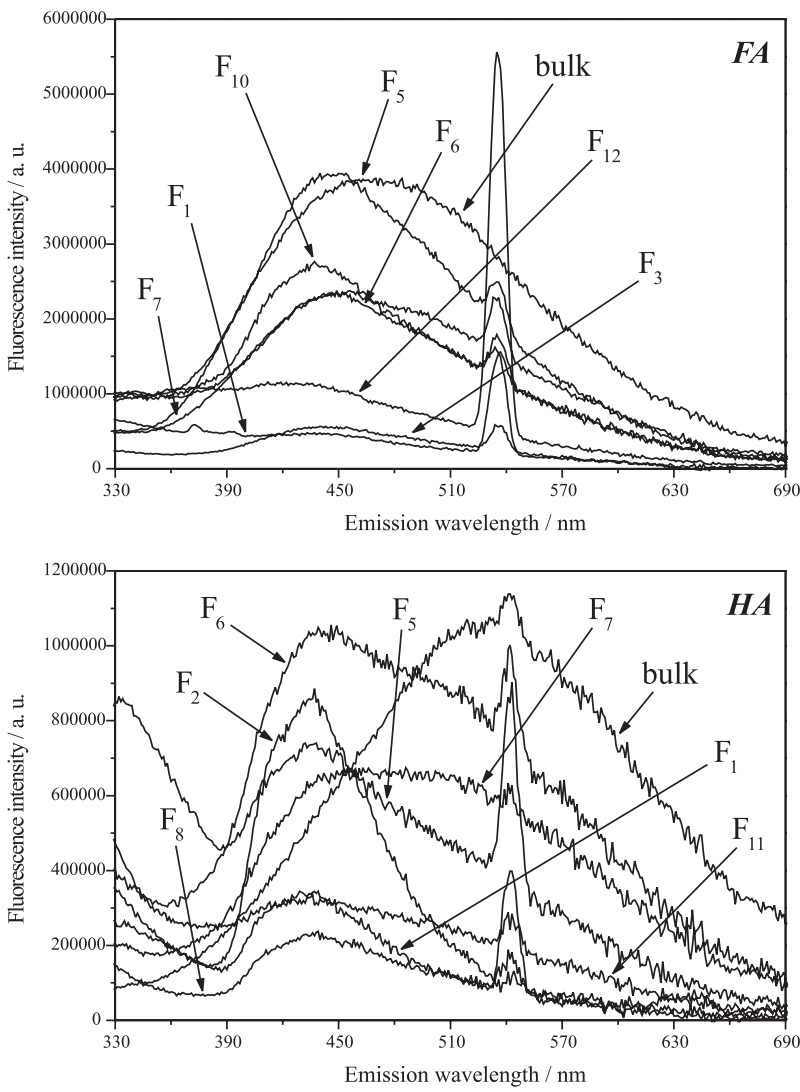

Figure 6. Single emission spectra $\left(\lambda_{\text {exc }}=270 \mathrm{~nm}\right)$ for the HPLC fractions. In order to facilitate comparisons, the intensities were normalized, with the spectrum of the FA bulk sample being multiplied by a factor of 1.2 and that of the HA, divided by a factor of 1.7 .

fractions agglomerates might also be present, but here, the fluorescence signal of individual structures is still dominant. Fraction 2, on the other hand, which consisted mainly of hydrophilic components, exhibits a discrete signal in the shorter wavelength range $(\sim 450 \mathrm{~nm})$.

The $\gamma$ peak is much better distinguished in the fractions than in the bulk sample diagrams for both, FA and HA (Figure 2). It is better visualized in the three-dimensional projections, being for $\mathrm{FA}$, located within the range exc/emi $=270-275 \mathrm{~nm} / 305-320 \mathrm{~nm}$ and for HA, in the range exc/emi $=270-275 \mathrm{~nm} / 330-345 \mathrm{~nm}$. As mentioned above, this peak is attributed to protein-derived compounds and its appearance is related to the incidence of freshly released material of biological origin. The occurrence of the $\gamma$ peak in all fractions, regardless of the degree of polarity of the elution solution, indicates that such proteinaceous moieties form part of the humic building block structures and are not solely associated with HS. Exhaustive examination of the infrared spectral properties, as well as of the acidity contents, of these same samples, has provided strong evidence of the presence of amide linkages. ${ }^{31,32,37}$ 

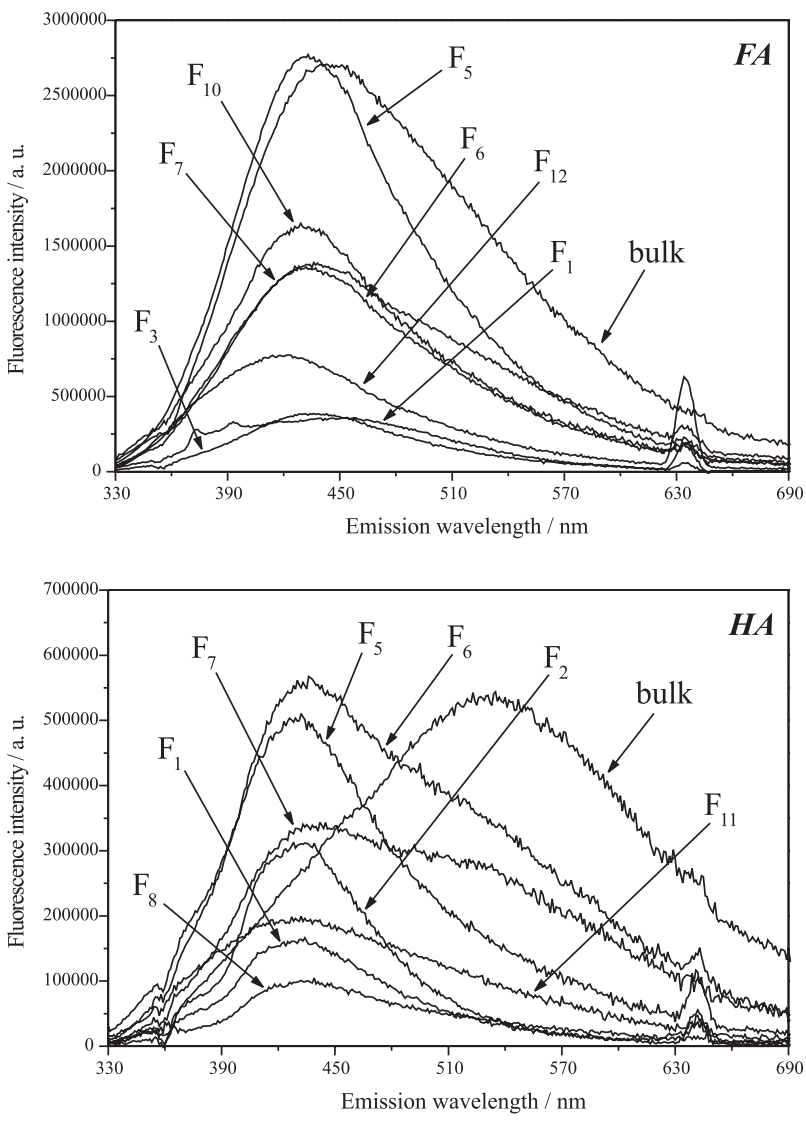

Figure 7. Single emission spectra $\left(\lambda_{\text {exc }}=320 \mathrm{~nm}\right)$ for the HPLC fractions. As in Fig. 6, the intensities were normalized, with the spectrum of the FA bulk sample being multiplied by 1.4 and that of the HA, divided by 1.6 .

The $\alpha^{\prime}$ peak can be well distinguished in most of the fractions, whereas the $\alpha$ peak is more like a shoulder and cannot, in most cases, be considered as a peak. For natural waters, the $\alpha^{\prime} / \alpha$ ratio has been employed to distinguish between fluorescent organic matter from terrestrial and marine environments with the highest values being measured in open-sea waters due to the reduced contribution of the $\alpha$ fluorophores in these environments. ${ }^{24,36,48}$ Terrestrial contributions are, in general, richer in aromatic (hydrophobic) moieties than marine contributions. Following this concept it would be expected to observe a higher appearance of the $\alpha$ components in the more hydrophobic fractions. In this regard, however, systematic behaviors were not observed here and, in most of the diagrams, the two peaks together composed a unique and broad band. In fact, the intensities of these two features increased or diminished simultaneously depending on the concentration of the solutions. Here again, this can be interpreted as a sign that typical HS fluorophores are present in all fractions regardless of their degree of polarity. It must be also taken into consideration that, differently to natural waters, which contain a great variety of organic compounds, HA and
FA receive a "sieved" chemical treatment representing, consequently, a particular group of structures.

\section{Conclusions}

Fractionation of FA and HA through a polarity gradient from pure water to pure acetonitrile with fluorescence detection and EEM fluorescence spectroscopy analysis revealed that both, FA and HA mixtures contain a pool of components of varied polarity. For FA and HA, all components are completely eluted with solutions of high to medium polarity, the HA components being slightly more hydrophobic $(60 \%$ acetonitrile to achieve total elution) than the FA components (50\% acetonitrile to achieve total elution). Contrary to the bulk solutions, fluorescence signals of the FA and HA fractions are basically identical, indicating that a primary group of fluorophores is at the origin of the fluorescence properties of both kinds of HS. These fluorophores are present in most of the fractions regardless of their degree of polarity. A bathochromic shift of the bulk solutions (mainly in HA) relative to the fraction emissions is attributed to a greater proximity of these fluorophores. For HA such proximity might be enhanced by the formation of aggregates with hydrophobic interiors. These results reinforce concepts according to which HS consist of assemblages of building blocks, with similar structural features.

\section{Acknowledgments}

This work was supported by the Conselho Nacional de Pesquisa e Desenvolvimento Científico e Tecnológico (CNPq, Brazil), the Coordenação de Aperfeiçoamento de Pessoal de Nível Superior (CAPES, Brazil) and the Conseil National de la Recherche Scientifique (CNRS, France). The careful reviews of two anonymous reviewers were considerably helpful in improving the manuscript.

\section{References}

1. Aiken, G.R.; McKight, D.M.; Wershaw, R.L.; MacCarthy, P.; Humic Substances in Soil, Sediment and Water: Geochemistry, Isolation and Characterization; John Wiley \& Sons: New York, 1985.

2. Hayes, M.H.B.; MacCarthy, P.; Malcolm, R.L.; Swift, R.S.; Humic Substances II in Search of Structure; John Wiley \& Sons: Chichester, 1989.

3. Allard, B.; Boren, H.; Grimvall, A.; Humic Substances in the 
Aquatic and Terrestrial Environment; Springer-Verlag: Berlin, 1991.

4. Senesi, N.; Miano, T.M.; Humic Substances in the Global Environment and Implications on Human Health; Elsevier: Amsterdam, 1994.

5. Schnitzer, M.; Soil Sci. 1990, 151, 41.

6. Stevenson, F.J.; Humus Chemistry: Genesis, Composition, Reactions; John Wiley \& Sons: New York, 1994.

7. Barceló, D.; Analyst 1991, 116, 681.

8. Chen, Z.; Xing, B.; McGill, W.B.; Dudas, M.J.; Can. J. Soil Sci. 1996, 76, 513.

9. Burba, P.; Rocha, J.C.; Klockow, D.; Fresenius J. Anal. Chem. 1994, 349, 800

10. Rocha, J.C.; Toscano, I.A.S.; Cardoso, A.A.; J. Braz. Chem. Soc. 1997, 8, 239.

11. Sargentini Jr., E.; Rocha, J.C.; Rosa, A.H.; Zara, L.F.; Santos, A.; Quim. Nova 2001, 24339.

12. Chin, Y.P.; Aiken, G.; O'Loughlin, E.; Environ. Sci. Technol. 1994, 28, 1853.

13. Peuravuori, J.; Pihlaja, K.; Anal. Chim. Acta 1997, 337, 133.

14. Muller, M.B.; Schmitt, D.; Frimmel, F.H.; Environ. Sci. Technol. 2000, 34, 4867.

15. Woelki, G.; Friedrich, S.; Hanschmann, G.; Salzer, R.; Fresenius J. Anal. Chem. 1997, 357, 548.

16. Lombardi, A.T.; Jardim, W.F.; Water Res. 1999, 33, 512.

17. Preube, G.; Friedrich, S.; Salzer, R.; Fresenius J. Anal. Chem. 2000, 368, 268.

18. Egeberg, P.K.; Alberts, J.A.; Water Res. 2002, 36, 4997.

19. Hutta, M.; Góra, R.J.; J. Chromatogr. A 2003, 1012, 67.

20. Alberts, J.J.; Takács, M.; Egeberg, P.K.; Org. Geochem. 2002, $33,817$.

21. Her, N.; Amy, G.; Foss, D.; Cho, J.; Yoon, Y.; Kosenka, P.; Environ. Sci. Technol. 2002, 36, 1069.

22. Coble, P.G.; Green, S.A.; Blough, N.V.; Gagosian, R.B.; Nature 1990, 348, 432.

23. Mopper, K.; Schultz, C.A.; Mar. Chem. 1993, 41, 229.

24. Coble, P.G.; Mar. Chem. 1996, 51, 325.

25. Del Castillo, C.E.; Coble, P.G.; Morell, J.M.; Lopez, J.M.; Corredor, J.E.; Mar. Chem. 1999, 66, 35.

26. Parlanti, E.; Wörz, K.; Geoffroy, L.; Lamotte, M.; Org. Chem. 2000, 31, 1765.

27. Baker, A.; Environ. Sci. Technol. 2001, 35, 948.

28. Chen, J.; LeBoeuf, E.J.; Dai, S.; Gu, B.; Chemosphere 2003, 50,639 .
29. Parlanti, E.; Morin, B.; Vacher, L.; Org. Chem. 2002, 33, 221.

30. Wu, F.C.; Evans, R.D.; Dillon, P.J.; Environ. Sci. Technol. 2003, 37, 3687 .

31. Giovanela, M.; Parlanti, E.; Soldi, M.S.; Soriano-Sierra, E.J.; Sierra, M.M.D.; Geochem. J. 2004, 38, 255.

32. Sierra, M.M.D.; Giovanela, M.; Parlanti, E.; Esteves, V.I.; Duarte, A.C.; Fransozo, A.; Soriano-Sierra, E.J.; J. Coast. Res. 2004, SI 42, 219.

33. Sierra, M.M.D.; Giovanela, M.; Parlanti, E.; Soriano-Sierra, E.J.; Chemosphere 2005, 58, 715.

34. Patel-Sorrentino, N.; Mounier, S.; Benaim, J.Y.; Water Res. 2002, 36, 2571.

35. Mayer, L.M.; Schick, L.L.; Loder III, T.C.; Mar. Chem. 1999, 64, 171.

36. Sierra, M.M.D.; Donard, O.F.X.; Lamotte, M.; Belin, C.; Ewald, M.; Mar. Chem. 1994, 47, 127.

37. Fernandes, A.N.; Giovanela, G.; Soriano-Sierra, E.J.; Sierra, M.M.D.; J. Coast. Res. 2004, SI 39, in press.

38. Senesi, N.; Anal. Chim. Acta 1990, 232, 77.

39. Steelink, C. In Implications of Elemental Characteristics of Humic Substances; Aiken, G.R.; McKnight, D.M.; Wershaw, R.L.; MacCarthy, P., eds.; Wiley Interscience: New York, 1985.

40. Picollo, A.; Nardi, S.; Concheri, G.; Chemosphere 1996, 33, 595.

41. Sein Jr, L.T.; Varnum, J.M.; Jansen, S.A.; Environ. Sci. Technol. 1999, 33, 546.

42. Cozzolino, A.; Conte, P.; Picollo, A.; Soil Biol. Biochem. 2001, 33, 563.

43. Del Vecchio, R.; Blough, N.V.; Environ. Sci. Technol. 2004, 38, 3885.

44. Yates, L.M.; Engebretson, R.R.; Haakenson, T.M.; von Wandruszka, R.; Anal. Chim. Acta 1997, 356, 295.

45. Ragle, C.S.; Engebretson, R.R.; von Wandruszka, R.; Soil Sci. 1997, 162, 106.

46. Rauen, T.G.; Madureira, L.A.S.; Debacher, N.A.; Sierra, M.M.D.; J. Coast. Res. 2004, SI 39, in press.

47. Sierra, M.M.D.; Rauen, T.G.; Debacher, N.A.; Soriano-Sierra, E.J.; Water Res. 2005, 39, 3811.

48. Sierra, M.M.D.; Donard, O.F.X.; Lamotte, M.; Mar. Chem., 1997, 58,51 .

Received: April 15, 2005

Published on the web: December 1, 2005 